\title{
THE PRESSURE-VOLUME RESPONSES OF HUMAN FOREARM VEINS DURING EPINEPHRINE AND NOREPINEPHRINE INFUSIONS ${ }^{1,2}$
}

\author{
By JOHN W. ECKSTEIN AND WILLIAM $\mathbf{K}$. HAMILTON \\ (From the Hemodynamic Laboratory, Cardiovascular Research Laboratories, Department of \\ Internal Medicine and the Division of Anesthesiology, Department of Surgery, \\ State University of Iowa College of Medicine, Iowa City, Iowa)
}

(Submitted for publication May 3, 1957; accepted August 23, 1957)

There has been some speculation concerning the importance of active constriction of the veins in the production of changes in the distribution of the blood volume in man (2). The veins are elastic and they undoubtedly exert some influence on blood volume distribution by their passive resistance to the distending force of intraluminal pressure. Recent observations show that forearm veins do constrict actively (3-8) in response to various stimuli. There is little direct quantitative information, however, to demonstrate that such a mechanism is capable of shifting significant amounts of blood out of the extremities. This study was undertaken to determine whether or not the venous constriction induced by epinephrine or norepinephrine infusion is sufficient to move important quantities of blood from the limbs.

\section{METHODS}

The plethysmographic determination of forearm venous volume requires the measurement of forearm venous distensibility by the method of Litter, Wood, and Wilkins $(7,9)$. For making this measurement, the forearm segment is enclosed in a tall plethysmograph and water is added to a level such that the pressure on the arm is greater than venous pressure but less than diastolic arterial pressure. The arterial inflow continues and drives venous pressure to a height greater than that of the water column. The difference between the internal and external pressure is the effective venous pressure. Under these conditions this is a small positive value less than $1.0 \mathrm{~mm}$. $\mathrm{Hg}$-regarded for practical purposes as zero pressure (7). The venous volume at this effective pressure also is small and constant (10). After the limb is fixed, a pneumatic cuff about the arm proximal to the plethysmograph is inflated in $1.0 \mathrm{~mm}$. $\mathrm{Hg}$ increments

1 Read in part by title at the Forty-ninth Annual Meeting of the American Society for Clinical Investigation in Atlantic City, N. J., May 6, 1957 (1).

2 Supported by a research grant (H-2644) from the National Heart Institute of the Public Health Service, and aided by a grant from the Iowa Heart Association. until the first perceptible increase in limb segment volume occurs. From this point of zero effective pressure, an additional pressure of $30 \mathrm{~mm}$. $\mathrm{Hg}$ is applied to the arm in $5.0 \mathrm{~mm}$. increments. This raises effective pressure in the forearm segment veins from 0 to $30 \mathrm{~mm}$. $\mathrm{Hg}$ by the same increments of $5.0 \mathrm{~mm}$. The increase in forearm venous volume caused by each pressure increment is recorded (Figure 1). A pressure-volume curve is constructed by plotting each volume level achieved at inflow-outflow equilibrium, expressed in $\mathrm{ml}$. per $100 \mathrm{ml}$. of forearm tissue, against the corresponding level of effective venous pressure (Figure 2). The curve so obtained is convex toward the volume axis. If venous distensibility decreases (Figure 2), a subsequent curve will fall below the control curve, nearer the pressure axis. Conversely, if venous distensibility increases, the subsequent curve falls above the control curve, nearer the volume axis. The final point on the curve, the volume which exists at an effective pressure of $30 \mathrm{~mm}$. $\mathrm{Hg}$, is termed arbitrarily the venous distensibility.

The pressure-volume curve obtained in this manner expresses the volume to which the forearm venous system is distended by any level of effective venous pressure between 0 and $30 \mathrm{~mm} . \mathrm{Hg}$. Assuming that venous distensibility is the same in both arms, the natural venous volume of the forearm segment is the volume coordinate of that point on the curve which corresponds to the natural venous pressure (effective venous pressure) in the unencumbered forearm. This procedure for measurement of forearm venous volume was employed in a recent investigation by Wood and Eckstein (6).

\section{PROCEDURES}

Twenty-four experiments were performed on 18 healthy men 23 to 28 years old. The subjects were studied in the supine position with room temperature maintained at $80^{\circ} \mathrm{F}$. They were nude except for shorts and a sheet covering the trunk and legs. The right forearm segment was enclosed in the plethysmograph. The arm was placed in the most comfortable position after it had been determined that varying arm position with respect to heart level did not alter venous distensibility. The plethysmographic water temperature was $89^{\circ} \mathrm{F}$. An arterial occluding cuff was applied to the wrist for inflation before each volume measurement. The arm cuff was placed so that increments of pressure did not alter the 


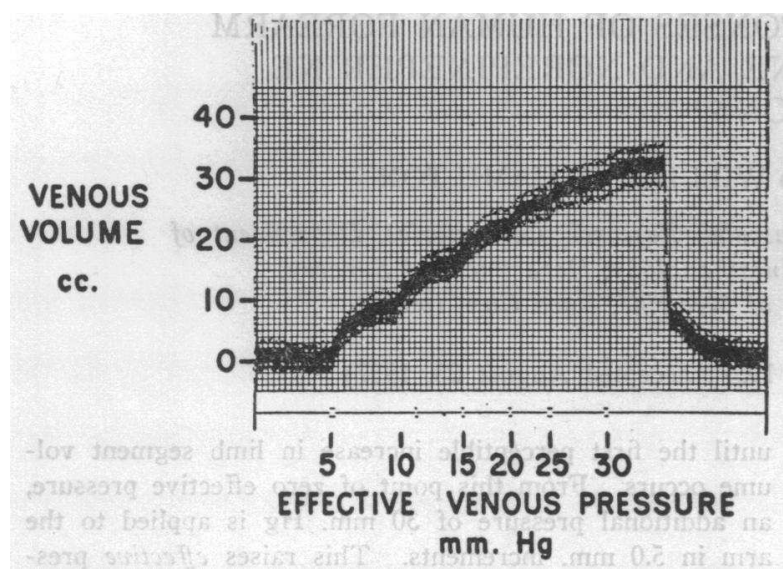

Fig. 1. Changes in Forearm Venous Volume ProDUCED BY KNOWN InCREMENTS OF EFfective Venous Pressure

position of the limb segment in relation to the plethysmograph. Forearm volume changes were measured with a Statham 0 to $5.0 \mathrm{~cm}$. $\mathrm{Hg}$ pressure transducer which sensed changes in the height of the water in a vertical cylinder attached to the top of the plethysmograph. The diameter of the cylinder was such that maximal volume increases within the plethysmograph raised the water level 1.5 to $2.0 \mathrm{~cm}$. The maximal error in effective pressure produced by this displacement was about $1.5 \mathrm{~mm}$. Hg. This occurred only at the peak of some volume records. Since the change in volume for a $5.0 \mathrm{~mm} . \mathrm{Hg}$ increment in effective pressure was small near the end of the volume record (Figure 1), this maximal pressure error caused only a negligible error in the measurement of limb volume above the baseline.

During the control period venous distensibility was measured intermittently in the right forearm. Simultaneous venous pressure measurements were made in the left antecubital vein with a Statham 0 to $5.0 \mathrm{~cm}$. $\mathrm{Hg}$ pressure transducer. Volume and pressure were recorded with a Sanborn direct-writing oscillograph. Arterial blood pressure was determined by means of a sphygmomanometer between venous pressure measurements, with a cuff on the arm proximal to the needle. Pulse rate was determined by palpation of a peripheral artery. After values for venous distensibility, venous pressure, pulse rate and arterial pressure had become stable, epinephrine or norepinephrine was infused into a foot vein at a constant rate with a calibrated pump. Epinephrine chloride was delivered at either 7.5 or $15.0 \mu \mathrm{g}$. per minute. Norepinephrine bitartrate was delivered at 15.0 or $30.0 \mu \mathrm{g}$. per minute. The baseline venous volume of the forearm was recorded continuously during the initial portion of the infusion period. Occasional, very small reductions in baseline venous volume were noted, but none of these exceeded $0.1 \mathrm{ml}$. per $100 \mathrm{ml}$. of forearm tissue. ${ }^{8}$ Five to

8 J. E. Wood and J. W. Eckstein in 1956 found occasional reductions in the baseline venous volume which seven minutes of infusion were required for venous pressure, pulse rate and arterial pressure to become stable at new levels. After stabilization, one or two measurements of venous distensibility were made. The infusion then was stopped and intermittent observations were made until control values returned. In certain experiments the epinephrine infusion was repeated at the same rate and for the same duration as in the initial infusion period. In other experiments epinephrine was infused a second time with the same rate and for the same duration after a single intravenous injection of $5.0 \mathrm{mg}$. of the adrenergic blocking agent phentolamine methanesulfonate (Regitine(9).4

Following the experiments, venous pressure-volume curves were constructed. The natural venous volume existing during each measurement of distensibility was obtained by drawing a line perpendicular to the pressure axis from the natural venous pressure value (Figure 2). The volume coordinate of the point at which this line intersected the curve was taken to be the natural venous volume. Control values for venous distensibility, volume and pressure are averages of the final three control measurements. Infusion values are single measurements obtained during epinephrine or norepinephrine infusion. If more than one set of measurements were made during infusion, the first set is reported.

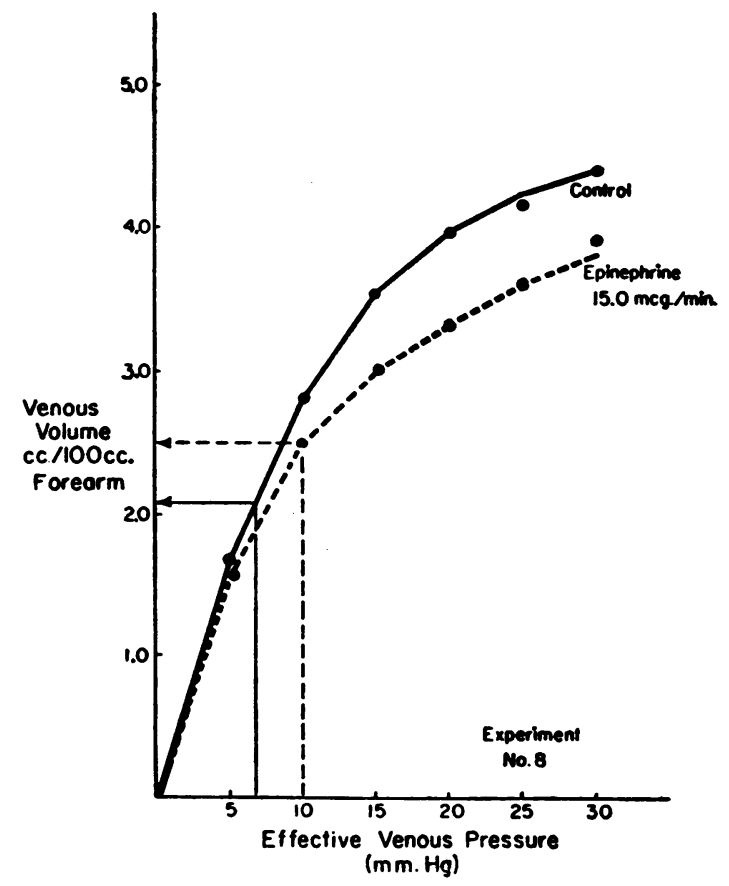

Fig. 2. Venous Pressure-Volume Curves Obtained During a Control Period and During an Epinephrine Infusion with the Forearm at Atrial Levet

ranged to $0.7 \mathrm{ml}$. per $100 \mathrm{ml}$. of forearm tissue when norepinephrine base was infused at $30.0 \mu \mathrm{g}$. per minute (11).

- Supplied by Ciba Pharmaceutical Products, Inc. 
RESULTS

Epinephrine infusion with left forearm at atrial level

In the first group of eight experiments (Table I) epinephrine was infused first at $7.5 \mu \mathrm{g}$. per minute and repeated at $15.0 \mu \mathrm{g}$. per minute after control values had been reestablished. In each experiment venous distensibility decreased and venous pressure increased during the infusion periods. Venous distensibility averaged $3.9 \mathrm{ml}$. per $100 \mathrm{ml}$. of forearm tissue during control periods, and fell to an average of 3.2 during infusion at 7.5 $\mu \mathrm{g}$. per minute. At an infusion rate of $15.0 \mu \mathrm{g}$. per minute the average value fell to $2.8 \mathrm{ml}$. per $100 \mathrm{ml}$. Venous pressure averaged $7.2 \mathrm{~mm} . \mathrm{Hg}$ during control periods, rose to an average of 8.9 at an infusion rate of $7.5 \mu \mathrm{g}$. per minute and rose still further to an average of 10.0 at an infusion rate of $15.0 \mu \mathrm{g}$. per minute. In many instances the pressure-volume curves obtained during epinephrine infusion fell very close to the control curves for the first 10 to $15 \mathrm{~mm}$. Hg increase in effective venous pressure (Figure 2). Beyond these levels the epinephrine curve moved away from the control curve toward the pressure axis. The natural pressure in the veins with the arm at atrial level $(10.0 \mathrm{~cm}$. above the back) often increased out of proportion to the decrease in venous distensibility so that at times blood appeared to shift into the forearm during epinephrine infusion. This relationship between pressure and distensibility with the arm at atrial level resulted in small, directionally inconsistent changes in natural forearm venous volume with infusions of 7.5 or $15.0 \mu \mathrm{g}$. per minute. There was essentially no change from the average control value of $1.6 \mathrm{ml}$. per $100 \mathrm{ml}$. of forearm tissue at either infusion rate.

\section{Epinephrine infusion with left forearm dependent}

In order to examine further and to quantitate more satisfactorily the volume shift of blood from the forearm veins which could be expected (on the basis of the preceding experiments) at higher natural venous pressure levels, the routine was changed in the second group of 11 experiments (Table II). Epinephrine was infused only at $\mathbf{1 5 . 0}$ $\mu g$. per minute and venous pressure was measured with the forearm approximately $14 \mathrm{~cm}$. below

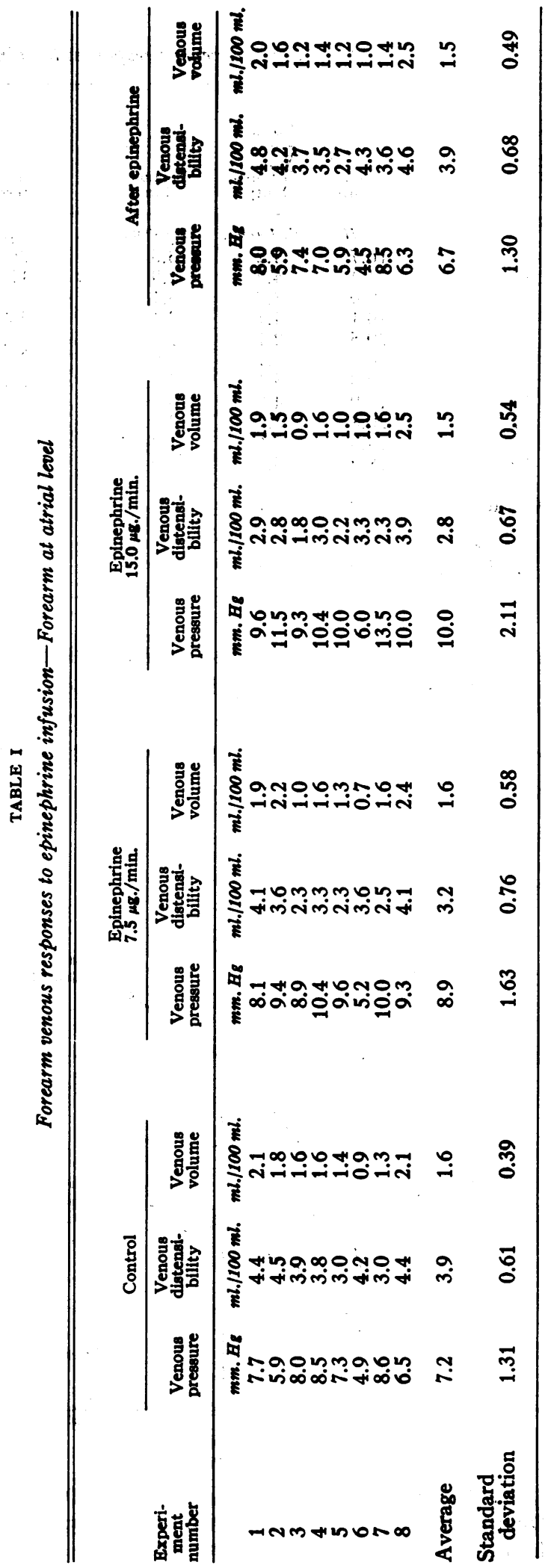


TABLE II

Forearm venous responses to epinephrine infusion-Forearm dependent

\begin{tabular}{|c|c|c|c|c|c|c|c|c|c|}
\hline \multirow[b]{2}{*}{$\begin{array}{c}\text { Experi- } \\
\text { ment } \\
\text { number }\end{array}$} & \multicolumn{3}{|c|}{ Control } & \multicolumn{3}{|c|}{$\begin{array}{l}\text { Epinephrine } \\
15.0 \mu \mathrm{g} . / \mathrm{min} .\end{array}$} & \multicolumn{3}{|c|}{ After epinephrine } \\
\hline & $\begin{array}{l}\text { Venous } \\
\text { pressure }\end{array}$ & $\begin{array}{c}\text { Venous } \\
\text { distensi- } \\
\text { bility }\end{array}$ & $\begin{array}{l}\text { Venous } \\
\text { volume }\end{array}$ & $\begin{array}{l}\text { Venous } \\
\text { pressure }\end{array}$ & $\begin{array}{l}\text { Venous } \\
\text { distensi- } \\
\text { bility }\end{array}$ & $\begin{array}{l}\text { Venous } \\
\text { volume }\end{array}$ & $\begin{array}{l}\text { Venous } \\
\text { pressure }\end{array}$ & $\begin{array}{c}\text { Venous } \\
\text { distensi- } \\
\text { bility }\end{array}$ & $\begin{array}{l}\text { Venous } \\
\text { volume }\end{array}$ \\
\hline $\begin{array}{r}9 \\
10 \\
11 \\
12 \\
13 \\
14 \\
15 \\
16 \\
17 \\
18 \\
19\end{array}$ & $\begin{array}{l}m m . \mathrm{Hg} \\
16.7 \\
14.4 \\
19.0 \\
20.1 \\
20.5 \\
20.6 \\
19.0 \\
19.9 \\
20.8 \\
19.8 \\
18.2\end{array}$ & $\begin{array}{c}m l . / 100 \mathrm{ml} . \\
4.2 \\
4.2 \\
3.8 \\
4.1 \\
2.7 \\
3.7 \\
3.1 \\
4.0 \\
3.1 \\
4.6 \\
3.7\end{array}$ & $\begin{array}{c}m l . / 100 \mathrm{ml} . \\
3.3 \\
2.9 \\
3.1 \\
3.4 \\
2.2 \\
2.9 \\
2.5 \\
3.3 \\
2.6 \\
4.0 \\
3.0\end{array}$ & $\begin{array}{c}m m . H g \\
20.3 \\
17.3 \\
24.8 \\
23.4 \\
22.7 \\
24.3 \\
22.6 \\
22.5 \\
26.2 \\
25.1 \\
22.5\end{array}$ & $\begin{array}{c}m l . / 100 \mathrm{ml} . \\
2.1 \\
3.1 \\
2.5 \\
3.1 \\
2.1 \\
2.7 \\
1.9 \\
2.7 \\
1.8 \\
2.3 \\
1.9\end{array}$ & $\begin{array}{c}m l . / 100 \mathrm{ml} . \\
1.7 \\
2.3 \\
2.3 \\
2.7 \\
1.8 \\
2.3 \\
1.6 \\
2.3 \\
1.6 \\
2.1 \\
1.6\end{array}$ & $\begin{array}{l}m m . H g \\
16.8 \\
15.3 \\
18.5 \\
20.1 \\
20.0 \\
20.6 \\
19.9 \\
20.3 \\
20.5 \\
20.8 \\
18.0\end{array}$ & $\begin{array}{c}m l . / 100 m l . \\
4.2 \\
4.3 \\
3.2 \\
4.1 \\
2.9 \\
3.4 \\
3.2 \\
4.8 \\
2.8 \\
4.3 \\
3.5\end{array}$ & $\begin{array}{c}m l .1100 \mathrm{ml} \\
3.5 \\
3.2 \\
2.8 \\
3.5 \\
2.5 \\
2.8 \\
2.7 \\
4.1 \\
2.3 \\
3.7 \\
2.7\end{array}$ \\
\hline Average & 19.0 & 3.7 & 3.0 & 23.0 & 2.4 & 2.0 & 19.2 & 3.8 & 3.1 \\
\hline $\begin{array}{l}\text { Standard } \\
\text { deviation }\end{array}$ & 1.92 & 0.57 & 0.49 & 2.30 & 0.47 & 0.38 & 1.80 & 0.67 & 0.56 \\
\hline
\end{tabular}

atrial level. Again venous distensibility decreased and venous pressure increased in each experiment during the infusion. Venous distensibility averaged $3.7 \mathrm{ml}$. per $100 \mathrm{ml}$. of forearm tissue during

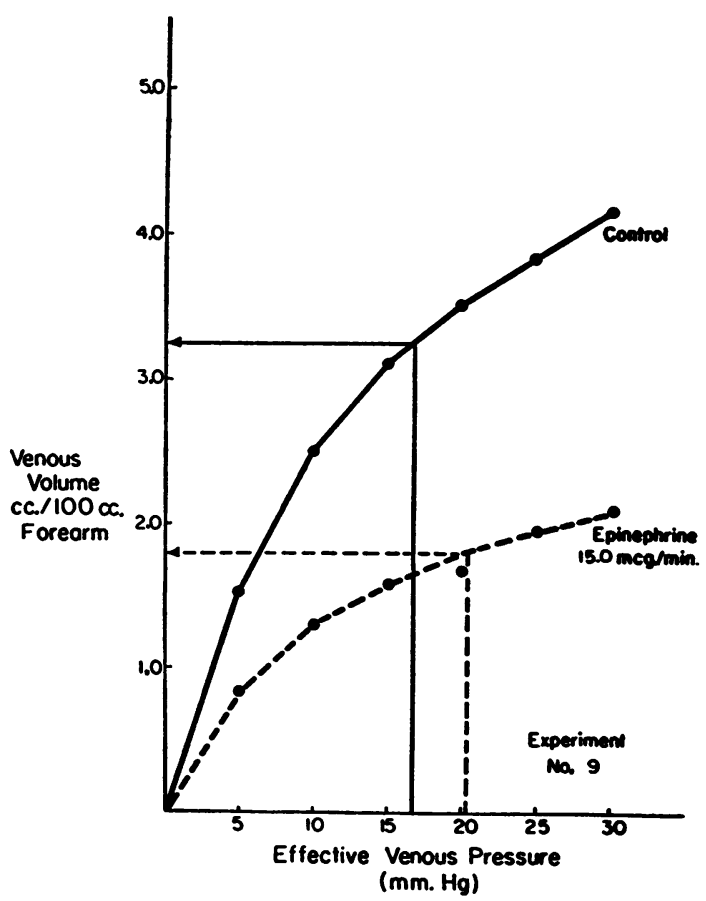

Fig. 3. Venous Pressure-Volume Curves Obtained During a Control Period and During an Epinephrine Infusion with the Forearm Dependent control periods and fell to an average of 2.4 during the infusion. Venous pressure averaged $19.0 \mathrm{~mm}$. $\mathrm{Hg}$ during control periods and increased to an average of 23.0 during the infusion. In each of these experiments, in which natural venous pressure was in the physiologic range existing normally

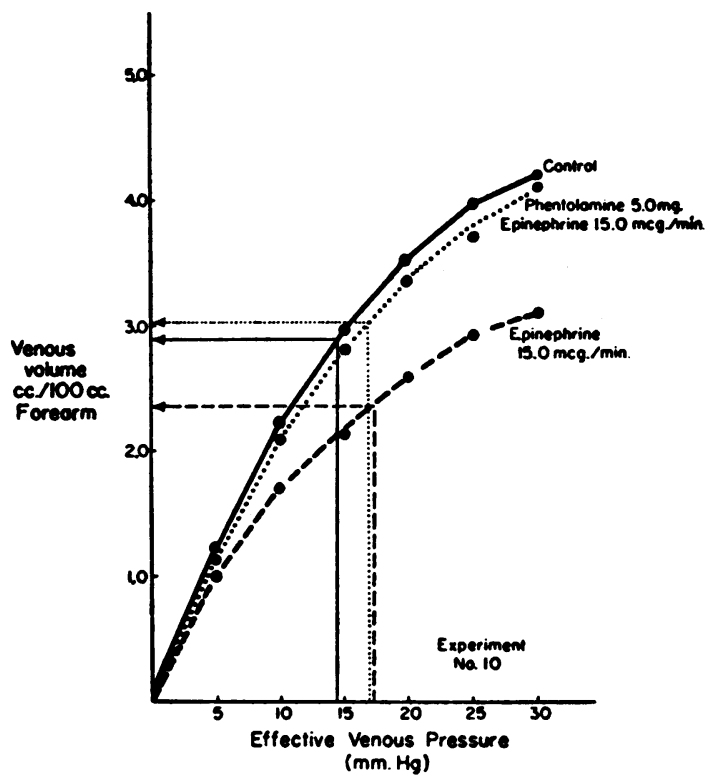

Fig. 4. Venous Pressure-Volume Curves Obtained During a Control Period, During an Epinephrine InfUsion, AND DURING AN EPINEPHRINe INfUSion FoLlowing Phentolamine with the Forearm Dependent 
in dependent forearms, the relationship between venous distensibility and pressure was such that epinephrine infusion resulted consistently in a shift of blood out of the forearm veins (Figures 3 and 4). The average venous volume during control periods was $3.0 \mathrm{ml}$. per $100 \mathrm{ml}$. of forearm tissue and fell to 2.0 during epinephrine infusionan average volume shift of 33 per cent.

\section{Norepinephrine infusion with left forearm de- pendent}

In five experiments (Table III), norepinephrine bitartrate was infused at $15.0 \mu \mathrm{g}$. per minute and repeated at $30.0 \mu \mathrm{g}$. per minute after control values had been reestablished. Venous pressure was measured with the left forearm approximately $14 \mathrm{~cm}$. below atrial level. Venous distensibility decreased and venous pressure increased in each case during the infusion. Venous distensibility averaged $3.9 \mathrm{ml}$. per $100 \mathrm{ml}$. of forearm tissue during control periods and fell to an average of 3.4 during infusion at $15.0 \mu \mathrm{g}$. per minute and to an average of 2.3 at an infusion rate of $30.0 \mu \mathrm{g}$. per minute. Venous pressure averaged $18.3 \mathrm{~mm}$. $\mathrm{Hg}$ during control periods, rose to an average of 22.2 at an infusion rate of $15.0 \mu \mathrm{g}$. per minute, and rose still further to an average of 25.4 at an infusion rate of $30.0 \mu \mathrm{g}$. per minute. The venous volume averaged $3.1 \mathrm{ml}$. per $100 \mathrm{ml}$. of forearm tissue during control periods and fell to an average of 2.8 at an infusion rate of $15.0 \mu \mathrm{g}$. per minute. At an infusion rate of $30.0 \mu \mathrm{g}$. per minute the average venous volume fell to $2.0 \mathrm{ml}$. per $100 \mathrm{ml}$. -an average volume shift of 35 per cent.

\section{Comparison between venous responses to epineph- rine and norepinephrine infusions}

The venous responses to epinephrine chloride infusion at $15.0 \mu \mathrm{g}$. per minute and the venous responses to norepinephrine bitartrate infusion at $30.0 \mu \mathrm{g}$. per minute may be compared since these infusion rates provide approximately equivalent amounts of sympatheticomimetic amine bases and since both groups of experiments were carried out with the forearm dependent (Tables II and III). Epinephrine infusion caused an average increase in venous pressure of $3.9 \pm 1.19 \mathrm{~mm}$. $\mathrm{Hg}$, while norepinephrine infusion caused an average venous

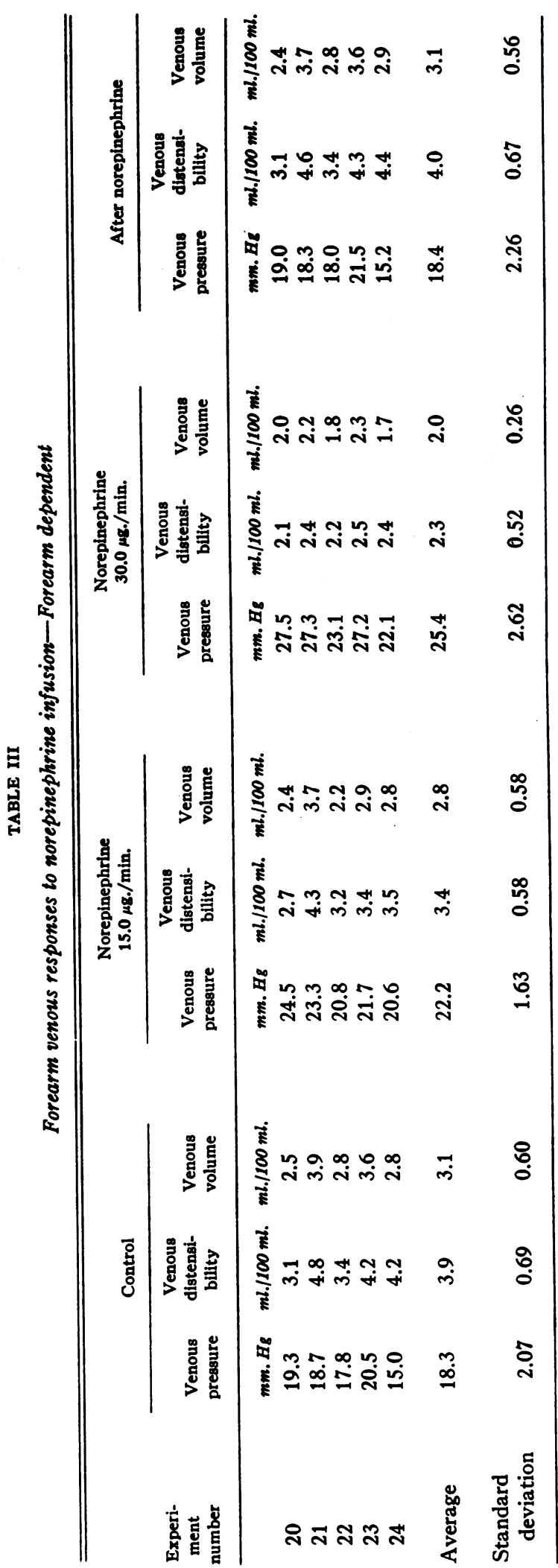


TABLE IV

Forearm venous responses to epinephrine infusion-Effects of repeated epinephrine infusion

\begin{tabular}{|c|c|c|c|c|c|c|c|c|c|}
\hline \multirow[b]{2}{*}{$\begin{array}{c}\text { Experi- } \\
\text { ment } \\
\text { number }\end{array}$} & \multicolumn{3}{|c|}{ Control } & \multicolumn{3}{|c|}{ 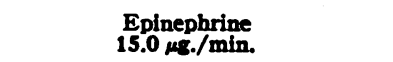 } & \multicolumn{3}{|c|}{$\begin{array}{l}\text { Repeat epinephrine } \\
15.0 \mathrm{\mu g} . / \mathrm{min} .\end{array}$} \\
\hline & $\begin{array}{l}\text { Venous } \\
\text { pressure }\end{array}$ & $\begin{array}{c}\text { Venous } \\
\text { distensi- } \\
\text { bility }\end{array}$ & $\begin{array}{l}\text { Venous } \\
\text { volume }\end{array}$ & $\begin{array}{l}\text { Venous } \\
\text { pressure }\end{array}$ & $\begin{array}{l}\text { Venous } \\
\text { distensi- } \\
\text { bility }\end{array}$ & $\begin{array}{l}\text { Venous } \\
\text { volume }\end{array}$ & $\begin{array}{l}\text { Venous } \\
\text { pressure }\end{array}$ & $\begin{array}{l}\text { Venous } \\
\text { distensi- } \\
\text { bility }\end{array}$ & $\begin{array}{l}\text { Venous } \\
\text { volume }\end{array}$ \\
\hline $\begin{array}{r}9 \\
11 \\
12 \\
15 \\
17 \\
18\end{array}$ & $\begin{array}{l}m m . H g \\
16.7 \\
19.0 \\
20.1 \\
19.0 \\
20.8 \\
19.8\end{array}$ & $\begin{array}{c}m l . / 100 m l . \\
4.2 \\
3.8 \\
4.1 \\
3.1 \\
3.1 \\
4.6\end{array}$ & $\begin{array}{c}m l . / 100 m l . \\
3.3 \\
3.1 \\
3.4 \\
2.5 \\
2.6 \\
4.0\end{array}$ & $\begin{array}{l}m m . H g \\
19.1 \\
24.8 \\
23.4 \\
22.6 \\
25.8 \\
25.1\end{array}$ & $\begin{array}{c}m l . / 100 \mathrm{ml} . \\
2.6 \\
2.5 \\
3.1 \\
1.9 \\
1.9 \\
2.3\end{array}$ & $\begin{array}{c}m l .1100 \mathrm{ml} . \\
2.0 \\
2.3 \\
2.7 \\
1.6 \\
1.8 \\
2.1\end{array}$ & $\begin{array}{l}\operatorname{mm.~Hg} \\
19.8 \\
23.8 \\
24.1 \\
21.6 \\
27.1 \\
26.6\end{array}$ & $\begin{array}{c}m l . / 100 \mathrm{ml} . \\
2.8 \\
2.5 \\
2.8 \\
2.5 \\
1.7 \\
2.3\end{array}$ & $\begin{array}{c}m l . / 100 \mathrm{ml} . \\
2.4 \\
2.3 \\
2.7 \\
2.2 \\
1.6 \\
2.1\end{array}$ \\
\hline Average & 19.3 & 3.8 & 3.2 & 23.4 & 2.4 & 2.1 & 23.8 & 2.4 & 2.2 \\
\hline $\begin{array}{l}\text { Standard } \\
\text { deviation }\end{array}$ & 1.42 & 0.61 & 0.56 & 2.28 & 0.46 & 0.39 & 2.82 & 0.41 & 0.37 \\
\hline
\end{tabular}

pressure increase of $7.2 \pm 1.31$. Epinephrine caused an average decrease in venous distensibility of $1.3 \pm 0.53 \mathrm{ml}$. per $100 \mathrm{ml}$. of forearm tissue, while norepinephrine caused an average decrease of $1.6 \pm 0.55$. Epinephrine caused an average fall in venous volume of $1.0 \pm 0.46 \mathrm{ml}$. per $100 \mathrm{ml}$., while norepinephrine caused an average fall of $1.1 \pm 0.45$. Despite the fact that norepinephrine caused a much greater rise in venous pressure than did epinephrine, the venous volume changes produced by these two materials were very similar since the slightly greater fall in venous distensibility with norepinephrine was sufficient to overcome the effect of the greater increase in distending pressure.
Epinephrine infusion repeated with and without prior administration of phentolamine

In six experiments, the epinephrine infusion was repeated at the same rate and for the same duration as the initial infusion. The venous pressure, distensibility and volume responses to epinephrine were found to be reproducible during repeated infusion (Table IV). In eight other experiments, the epinephrine infusion was repeated under the same conditions after a single intravenous injection of $5.0 \mathrm{mg}$. of phentolamine. In each case the decrease in venous distensibility and the increase in venous pressure were much less when epinephrine was infused after phentolamine administration (Table V). In the three phentola-

TABLE V

Forearm venous responses to epinephrine infusion-Effects of repeated epinephrine infusion after phentolamine

\begin{tabular}{|c|c|c|c|c|c|c|c|c|c|}
\hline \multirow[b]{2}{*}{$\begin{array}{c}\text { Experi- } \\
\text { ment } \\
\text { number }\end{array}$} & \multicolumn{3}{|c|}{ Control } & \multicolumn{3}{|c|}{$\begin{array}{l}\text { Epinephrine } \\
15.0 \text { ks./min. }\end{array}$} & \multicolumn{3}{|c|}{$\begin{array}{l}\text { Repeat epinephrine } \\
15.0 \text { me./min. } \\
\text { (after phentolamine) }\end{array}$} \\
\hline & $\begin{array}{l}\text { Venous } \\
\text { pressure }\end{array}$ & $\begin{array}{l}\text { Venous } \\
\text { distensi- } \\
\text { bility }\end{array}$ & $\begin{array}{l}\text { Venous } \\
\text { volume }\end{array}$ & $\begin{array}{l}\text { Venous } \\
\text { pressure }\end{array}$ & $\begin{array}{l}\text { Venous } \\
\text { distensi- } \\
\text { bility }\end{array}$ & $\begin{array}{l}\text { Venous } \\
\text { volume }\end{array}$ & $\begin{array}{l}\text { Venous } \\
\text { pressure }\end{array}$ & $\begin{array}{l}\text { Venous } \\
\text { distensi- } \\
\text { billty }\end{array}$ & $\begin{array}{l}\text { Venous } \\
\text { volume }\end{array}$ \\
\hline $\begin{array}{r}2 \\
3 \\
4 \\
5 \\
6 \\
10 \\
13 \\
14\end{array}$ & $\begin{array}{c}m m . H 8 \\
5.9 \\
8.0 \\
8.5 \\
7.3 \\
4.9 \\
14.4 \\
20.5 \\
20.6\end{array}$ & $\begin{array}{c}m l . / 100 \mathrm{ml} . \\
4.5 \\
3.9 \\
3.8 \\
3.0 \\
4.2 \\
4.2 \\
2.7 \\
3.7\end{array}$ & $\begin{array}{l}m l .1100 \mathrm{ml} . \\
1.8 \\
1.6 \\
1.6 \\
1.4 \\
0.9 \\
2.9 \\
2.2 \\
2.9\end{array}$ & $\begin{array}{c}m m . H 8 \\
11.5 \\
9.3 \\
10.4 \\
10.0 \\
6.0 \\
17.3 \\
22.7 \\
24.3\end{array}$ & $\begin{array}{c}m l . / 100 \mathrm{ml} . \\
2.8 \\
1.8 \\
3.0 \\
2.2 \\
3.3 \\
3.1 \\
2.1 \\
2.7\end{array}$ & $\begin{array}{c}m \mathrm{ml} .100 \mathrm{ml} . \\
1.5 \\
0.9 \\
1.6 \\
1.0 \\
1.0 \\
2.3 \\
1.8 \\
2.3\end{array}$ & $\begin{array}{c}m m . H E \\
8.1 \\
6.7 \\
7.8 \\
5.9 \\
4.3 \\
16.8 \\
21.0 \\
20.8\end{array}$ & $\begin{array}{c}m l . / 100 \mathrm{ml} . \\
3.6 \\
3.4 \\
3.5 \\
2.5 \\
4.3 \\
4.0 \\
2.4 \\
3.0\end{array}$ & $\begin{array}{c}\mathrm{ml} . / 100 \mathrm{ml} . \\
1.4 \\
1.0 \\
1.9 \\
1.2 \\
0.9 \\
3.1 \\
2.2 \\
2.4\end{array}$ \\
\hline Average & 11.5 & 3.8 & 1.9 & 13.9 & 2.6 & 1.6 & 11.4 & 3.3 & 1.8 \\
\hline $\begin{array}{l}\text { Standard } \\
\text { deviation }\end{array}$ & 6.40 & 0.72 & 0.71 & 6.70 & 0.53 & 0.57 & 6.93 & 0.67 & 0.80 \\
\hline
\end{tabular}


mine experiments (Nos. 10,13 and 14) in which venous pressure was measured with the forearm dependent, the phentolamine likewise appeared to prevent the fall in forearm venous volume which had been produced regularly by epinephrine infusion alone (Figure 4).

The reduction in the venous responses to epinephrine infusion following phentolamine administration are probably due to the adrenergic blocking action of the latter drug rather than to its direct vasodilating action (12), since in two experiments phentolamine administration ( $5.0 \mathrm{mg}$.) alone caused no change in venous distensibility.

\section{DISCUSSION}

The peripheral venous system may be considered an extension of the .central vascular reservoir (great veins and pulmonary vessels) from which blood is pumped by the heart. The volume and pressure within the central reservoir are important determinants of the cardiac output, and under steady conditions they are in equilibrium with it. An increase in cardiac output must be associated with a pressure-volume readjustment within the reservoir which increases the availability of blood to the heart. Such a readjustment also must require a reduction in capacity of the peripheral venous system and a shift of blood centrally, i.e., an increased venous return. Of the many factors involved in the regulation of venous return, probably the least is known about the quantitative importance of active venous constriction. Since the veins probably contain at least 75 per cent of the blood volume (2), even a relatively slight amount of venous contraction might be expected to move appreciable amounts of blood.

If one assumes that the pressure-volume responses of the veins of the arms and legs are similar, it becomes possible to estimate the total amount of blood shifted out of the extremities by the venous constriction caused by epinephrine and norepinephrine infusion. Litter and Wood (10) found the average vascular volume of the leg of a supine subject (effective venous pressure about $8 \mathrm{~mm} . \mathrm{Hg}$ ) to be approximately $3.5 \mathrm{ml}$. per 100 $\mathrm{ml}$. of leg tissue. If the average volume of each upper extremity is four liters (10) and each lower extremity 13 liters (13), the average total blood volume of the four limbs would be approximately
$1,200 \mathrm{ml}$. This value is in agreement with that of Ebert and Stead (14), who found the average blood volume of one upper and two lower extremities to be $900 \mathrm{ml}$. Litter and Wood (9) also found that at an effective venous pressure of $30 \mathrm{~mm}$. $\mathrm{Hg}$ the average venous volume of the leg was $4.75 \mathrm{ml}$. per $100 \mathrm{ml}$. We found that at an effective venous pressure of $30 \mathrm{~mm}$. $\mathrm{Hg}$, the average venous volume of the forearm was $3.7 \mathrm{ml}$. per $100 \mathrm{ml}$. (Table I). Sjöstrand (15) pointed out that an average of more than $600 \mathrm{ml}$. of blood was shifted from the lower extremities when standing subjects assumed the reclining position. Furthermore, Ebert and Stead (14) found that an average of $720 \mathrm{ml}$. of blood could be pooled in one upper and two lower extremities by venous tourniquets. From these figures it is apparent that the venous volume of four dependent extremities probably exceeds 1,500 $\mathrm{ml}$. Under the conditions of our experiments, epinephrine and norepinephrine infusions caused shifts of blood out of the forearm which averaged 34 per cent. Based on the observations cited above, this shift in terms of the four extremities would amount to more than $500 \mathrm{ml}$. This quantity of blood, returned from the limbs alone, would represent an appreciable fraction of the estimated normal central blood volume, which is probably less than $1,200 \mathrm{ml}$. (16).

Our contention that much of this blood shifts centrally is supported by the work of Ranges and Bradley (17), who found increases in right atrial pressure in man following administration of epinephrine; and by the observations of Bondurant, Hickam, and Isley (18), who found increases in central venous pressure in man during norepinephrine infusion. Furthermore, Rashkind, Lewis, Henderson, Heiman, and Dietrick (19) found an increase in the volume of a central venous reservoir (which collected the total venous return) in dogs in response to the administration of epinephrine and norepinephrine. Freis and Rose (20) also demonstrated an increase in central reservoir volume and an associated increase in right ventricular output during the administration of norepinephrine to dogs. Peripheral venous constriction, with the resulting increase in venous return, may contribute to the increase in cardiac output observed in normal man during epinephrine infusion (21) and in dogs in early experimental hemor- 
rhagic shock during treatment with norepinephrine (22).

Wood, Litter, and Wilkins (7) demonstrated that reductions in forearm venous distensibility are present in patients with congestive heart failure who have elevated venous pressure. This reduction in distensibility, compared with values observed in compensated patients, averaged 1.5 $\mathrm{ml}$. per $100 \mathrm{ml}$. This diminution in venous distensibility in a chronic condition corresponds closely with our reduction values of 1.3 and $1.6 \mathrm{ml}$. per $100 \mathrm{ml}$. for epinephrine and norepinephrine effects, respectively, during acute administration. In the experimental situation with these two hormones, the shift of blood out of the extremities, presumably centrad, probably serves to augment the cardiac output. From a teleologic standpoint, it appears that the same venous response would be generally desirable in congestive heart failure, inasmuch as the primary physiologic abnormality is a subnormal cardiac output. However, in the severe pulmonary vascular engorgement, associated with acute left ventricular decompensation, it might aggravate the abnormality. Venisection or application of tourniquets to the extremities probably relieves the emergency situation by diminishing the effectiveness of this natural venomotor response in the presence of a normal right ventricular myocardium.

\section{SUMMARY}

Forearm venous distensibility, pressure and volume were measured during 24 experimental sessions in man before and during epinephrine infusion, during epinephrine infusion following phentolamine administration, following phentolamine administration alone, and before and during norepinephrine infusion. The following observations were made :

1. Forearm venous distensibility decreased while venous pressure increased during epinephrine infusion in each of 19 experiments. Epinephrine infusions repeated under the same conditions produced quantitatively similar venous pressure and distensibility responses in each of six experiments.

2. These epinephrine responses were smaller in each of eight experiments when phentolamine was administered prior to repetition of the epinephrine infusion. In two other experiments there was no change in venous distensibility when phentolamine was administered alone.

3. Norepinephrine caused a much greater rise in venous pressure and a slightly greater fall in venous distensibility than did epinephrine in comparable doses.

4. With subjects at rest in the supine position with the forearm at atrial levels, epinephrine produced only small inconsistent changes in forearm venous volume.

5. When the forearm was dependent, both epinephrine and norepinephrine infusions regularly caused large shifts of blood of comparable magnitude out of the forearm veins. It is suggested that such venous volume shifts from the dependent extremities in man's upright position to the central venous reservoir may be important in augmenting the cardiac output at times of physiologic need.

\section{REFERENCES}

1. Eckstein, J. W., and Hamilton, W. K., The pressurevolume characteristics of human forearm veins during epinephrine infusion (abstract). J. Clin. Invest., $1957,36,886$.

2. Landis, E. M., and Hortenstine, J. C., Functional significance of venous blood pressure. Physiol. Rev., 1950, 30, 1.

3. Duggan, J. J., Love, V. L., and Lyons, R. H., A study of reflex venomotor reactions in man. Circulation, 1953, 7, 869.

4. Page, E. B., Hickam, J. B., Sieker, H. O., McIntosh, H.D., and Pryor, W. W., Reflex venomotor activity in normal persons and in patients with postural hypotension. Circulation, 1955, 11, 262.

5. Wood, J. E., and Eckstein, J. W., Peripheral venous responses to environmental temperature change in man. Federation Proc., 1956, 15, 623.

6. Wood, J. E., and Eckstein, J. W., Peripheral venous and arteriolar responses to moderate reductions in effectively circulating blood volume in man (abstract). J. Clin. Invest., 1956, 35, 746.

7. Wood, J. E., Litter, J., and Wilkins, R. W., Peripheral venoconstriction in human congestive heart failure. Circulation, 1956, 13, 524.

8. Burch, G. E., and Murtadha, M., A study of the venomotor tone in a short intact venous segment of the forearm of man. Am. Heart J., 1956, 51, 807.

9. Litter, J., and Wood, J. E., The venous pressurevolume curve of the human leg measured in vivo (abstract). J. Clin. Invest., 1954, 33, 953.

10. Litter, J., and Wood, J. E., The volume and distribution of blood in the human leg measured in vivo. I. The effects of graded external pressure. J. Clin. Invest., 1954, 33, 798.

11. Wood, J. E., and Eckstein, J. W., Unpublished observations. 
12. Goodman, L. S., and Gilman, A., The Pharmacological Basis of Therapeutics, 2nd ed. New York, The Macmillan Co., 1955, p. 584.

13. Asmussen, E., The distribution of the blood between the lower extremities and the rest of the body. Acta physiol. Scandinav., 1943, 5, 31.

14. Ebert, R. V., and Stead, E. A., Jr., The effect of the application of tourniquets on the hemodynamics of the circulation. J. Clin. Invest., 1940, 19, 561.

15. Sjöstrand, T., Volume and distribution of blood and their significance in regulating the circulation. Physiol. Rev., 1953, 33, 202.

16. Doyle, J. T., Wilson, J. S., Lépine, C., and Warren, J. V., An evaluation of the measurement of the cardiac output and of the so-called pulmonary blood volume by the dye-dilution method. J. Lab. \& Clin. Med., 1953, 41, 29.

17. Ranges, H. M., and Bradley, S. E., Systemic and renal circulatory changes following the administration of adrenin, ephedrine, and paredrinol to normal man. J. Clin. Invest., 1943, 22, 687.
18. Bondurant, S., Hickam, J. B., and Isley, J. K., Pulmonary and circulatory effects of acute pulmonary vascular engorgement in normal subjects. J. Clin. Invest., 1957, 36, 59.

19. Rashkind, W. J., Lewis, D. H., Henderson, J. B., Heiman, D. F., and Dietrick, R. B., Venous return as affected by cardiac output and total peripheral resistance. Am. J. Physiol., 1953, 175, 415.

20. Freis, E. D., and Rose, J. C., The sympathetic nervous system, the vascular volume and the venous return in relation to cardiovascular integration. Am. J. Med., 1957, 22, 175.

21. Goldenberg, M., Pines, K. L., Baldwin, E. de F., Greene, D. G., and Roh, C. E., The hemodynamic response of man to nor-epinephrine and epinephrine and its relation to the problem of hypertension. Am. J. Med., 1948, 5, 792.

22. Gilmore, J. P., Smythe, C. M., and Handford, S. W., The effect of 1-norepinephrine on cardiac output in the anesthetized dog during graded hemorrhage. J. Clin. Invest., 1954, 33, 884. 